\title{
19. CHERTS FROM THE WESTERN PACIFIC, LEG 7, DEEP SEA DRILLING PROJECT
}

\author{
G. R. Heath, Department of Oceanography, Oregon State University, Corvallis, Oregon \\ and \\ Ralph Moberly, Jr., Hawaii Institute of Geophysics, University of Hawaii, Honolulu, Hawaii
}

\begin{abstract}
Nodular and bedded cherts are present at all sites drilled on Leg 7. Nodules are usually associated with carbonates, but also occur in siliceous sequences. Bedded cherts, usually porcelaneous, are restricted to noncarbonate deposits. Textural and mineralogical characteristics suggest that deep-sea cherts form in two stages. In the first stage, biogenous opal is dissolved and reprecipitated as finely crystalline cristobalite to produce porous porcelanites. The cristobalite is either deposited as interstitial matrix, or replaces pre-existing calcite or montmorillonite. In the second stage, the cristobalite inverts to quartz, and the remaining porosity is lost. The end product is a classic dense vitreous chert. The second stage inversion may be primarily a solid-solid zero-order reaction of the type described by Ernst and Calvert. Neither the mineralogy nor texture of cherts is related to the age of enclosing sediments in a simple way. However, the occurrence of quartz-rich cherts seems to be favored by higher-thanaverage temperatures in the sediment.
\end{abstract}

\section{INTRODUCTION}

Chert or porcelanite was sampled at all seven sites drilled on Leg 7 (Figure 1, Table 1). The ages, associated lithotypes, textural characteristics and mineral compositions of these rocks are varied enough to make them ideal subjects for a preliminary evaluation of the nature and geological significance of deep-sea cherts.

Many characteristics of the Leg 7 siliceous deposits are strongly reminiscent of the Monterey Formation of California (Bramlette, 1946; Ernst and Calvert, 1969). Such features as the association of biogenous silica, cristobalitic porcelanite, and quartz-rich chert, as well as the irregular distribution of silicification phenomena, are shared by the outcropping and deep-sea deposits. Thus, it is possible to reinforce arguments based on sparse drill-hole data with evidence from exposed sections where the spatial relationship of the various forms of silica are more clearcut.

TABLE 1. Cherts and Porcelanites Recovered on Leg 7, Deep Sea Drilling Project

61-0-1-CC

Silicified laminated siltstone, light brownish-gray (5YR6-4/1). Radiolarian.

Age: Santonian-early Campanian.
TABLE 1 - Continued

\begin{tabular}{|c|c|}
\hline & White silty chert. Radiolarian. \\
\hline $61-1-1-1$ & $\begin{array}{l}\text { Grayish-yellow brown }(10 \text { Y R5/1) } \\
\text { porcelanite. Radiolarian. }\end{array}$ \\
\hline 61-1-1-CC & $\begin{array}{l}\text { Chert nodule. Olive gray }(5 Y 4 / 1) \\
\text { and light yellowish-gray }(25 Y 7 / 1) \text {. } \\
\text { Dense vitreous core, porous porce- } \\
\text { laneous radiolarian rind. }\end{array}$ \\
\hline $62-0-6-1$ & $\begin{array}{l}\text { Light olive gray (5Y6-7/1) nodular } \\
\text { chert intergrown with chalky nan- } \\
\text { nofossil limestone. No siliceous } \\
\text { microfossils. } \\
\text { Age: Late late Oligocene (N3). }\end{array}$ \\
\hline $62-0-6-\mathrm{CC}$ & As $62-0-6-1$. \\
\hline $63-0-7-2$ & $\begin{array}{l}\text { Dark yellow brown (10YR3/2) } \\
\text { vitreous chert. No siliceous micro- } \\
\text { fossils. } \\
\text { Age: Middle Oligocene (early } \\
\text { N2). }\end{array}$ \\
\hline 64-1-11-CC & $\begin{array}{l}\text { Light gray (N6-N7) to olive gray } \\
\text { (5Y5/1) nodular chert. No sili- } \\
\text { ceous microfossils. } \\
\text { Age: Late Middle Eocene (P12- } \\
\text { P14). }\end{array}$ \\
\hline
\end{tabular}


TABLE 1 - Continued

\begin{tabular}{|c|c|}
\hline $65-0-14-\mathrm{CC}$ & $\begin{array}{l}\text { Porcelanite or porcelaneous mud- } \\
\text { stone. Dark brownish-gray ( } 5 \mathrm{YR} \text { - } \\
\text { 3/1). Radiolarian. } 125.5 \text { meters. } \\
\text { Age: Earliest Oligocene. }\end{array}$ \\
\hline \multirow[t]{2}{*}{$65-0-17-\mathrm{CC}$} & As $65-0-14-\mathrm{CC}$. \\
\hline & $\begin{array}{l}\text { Silicified laminated arenite (tur- } \\
\text { bidite). Pale yellowish-brown (10- } \\
\text { YR6/3). Radiolarian. } 137.5 \text { meters. } \\
\text { Age: Middle-late Eocene. }\end{array}$ \\
\hline $65-1-1-\mathrm{CC}$ & $\begin{array}{l}\text { Dark brownish-gray porcelanite } \\
\text { and plae yellowish-brown silicified } \\
\text { arenite as } 65-0-14-\mathrm{CC} \text { and } 65-0 \text { - } \\
\text { 17-CC. }\end{array}$ \\
\hline $65-1-2-\mathrm{CC}$ & As $65 \cdot 1-1-\mathrm{CC}$. \\
\hline $65-1-3-\mathrm{CC}$ & As $65-1-1-\mathrm{CC}$. \\
\hline $65-1-4$ and $65-1-5$ & $\begin{array}{l}\text { Contain cavings of silicified rock } \\
\text { described above. }\end{array}$ \\
\hline $66-0-4-\mathrm{CC}$ & $\begin{array}{l}\text { Porcelanite grading to cristobalitic } \\
\text { mudstone. Brownish-black (10YR- } \\
\text { 2/1) to dark yellowish-brown } \\
\text { (10YR3/2). Radiolarian. } \\
\text { Age: Late Oligocene (extrapolat- } \\
\text { ing sedimentation rates). }\end{array}$ \\
\hline \multirow[t]{2}{*}{$66-0-5-\mathrm{CC}$} & As $66-0-4-\mathrm{CC}$. \\
\hline & $\begin{array}{l}\text { Laminated silicified siliceous tur- } \\
\text { bidite or turbidite porcelanite. } \\
\text { Moderate yellowish-brown (10YR- } \\
5 / 4) \text { and grayish-orange pink } \\
\text { (5YR7/2). Radiolarian. } \\
\text { Age: Late Oligocene (extrapolat- } \\
\text { ing sedimentation rates). }\end{array}$ \\
\hline \multirow[t]{2}{*}{$67-1-2-\mathrm{CC}$} & $\begin{array}{l}\text { Porcelanite. Dusky yellowish- } \\
\text { brown }(10 \text { Y } 7 / 2) \text { ? Radiolarian. } \\
\text { Age: Possibly late Early Eocene. }\end{array}$ \\
\hline & $\begin{array}{l}\text { Laminated porcelanite. Pale yel- } \\
\text { lowish-brown }(10 \mathrm{YR} 7 / 3) . ? \text { Radio- } \\
\text { larian. }\end{array}$ \\
\hline
\end{tabular}

\section{FIELD CHARACTERISTICS}

The cherts and porcelanites collected on Leg 7 fall into two major classes, corresponding in a general way to the nodular and bedded cherts of the geological literature.

The nodules are the typical form encountered in carbonate sequences (Sites 62, 63, 64), but, as shown by the occurrences at Sites 61 and 67 , they are not restricted to such sequences. Nodules small enough to enter the 5 centimeter coring bit have been sampled complete. More commonly, only fragments (usually milled by grinding at the bottom of the hole) or cored sections are recovered. Some idea of the maximum size of deep-sea nodules is revealed by dredged samples. The largest of these have horizontal dimensions in excess of 2 by 1 meters, and are as much as 10 centimeters thick. Such nodules are comparable in size and shape to those recorded in exposed carbonate sequences of many geological ages and from numerous localities throughout the world.

The deep-sea nodules range from simple triaxial ellipsoids to irregular anastomosing bodies of silica, which are often rich in chalk inclusions, and grade unpredictably to ordinary chalk. The suggestion that the geometrical complexity of chert nodules decreases with the proportion of impurities in the enclosing limestone (Sujkowski, 1958) is not borne out by the Leg 7 samples. The complexity bears no simple relation to the composition of the associated carbonate, nor to any other obvious parameters such as depth of burial or age of enclosing sediment.

The mode of formation of the nodular chert is discussed in more detail in a subsequent section. However, in general, the silica appears to replace individual carbonate particles, and often pseudomorphs fine details of the former calcite tests.

The second group of cherts, the bedded type, is found in both siliceous oozes and pelagic clays, but never in the pelagic carbonates. Because bedded chert has not been dredged and since the Leg 7 occurrences are not quite like bedded cherts on land, little of their lateral dimensions or of the nature of their lateral aboundaries can be inferred. J. Ewing (personal communication) has observed that the upper surface of the chert sequence in the Central Basin consists of numerous discontinuous reflectors (evidenced by overlapping hyperbolae on the $3.5-\mathrm{kHz}$ reflection records). Thus, individual silicified layers may cover as little as a few square meters, and probably rarely exceed a few thousand square meters in extent.

The thickness of silicified beds is usually in the 2 to 5 centimeter range. Few layers thicker than 10 centimeters were encountered on Leg 7. Individual beds at Sites 65 and 66 are separated by one to several meters of apparently unaltered siliceous ooze. Unfortunately, the alternation of extremely hard and soft unconsolidated material is virtually impossible to sample adequately using existing coring techniques. Thus, the nature of the ooze-porcelanite contacts is poorly known. A few of the porcelanite fragments retain adjacent softer sediment. In these cases, the boundary is gradational over a few millimeters.

The bedded cherts encountered during Leg 7 appear to represent an early stage in the formation of the classic bedded sequences observed on land. The presence of abundant reactive silica (opal) suggests that only time is 


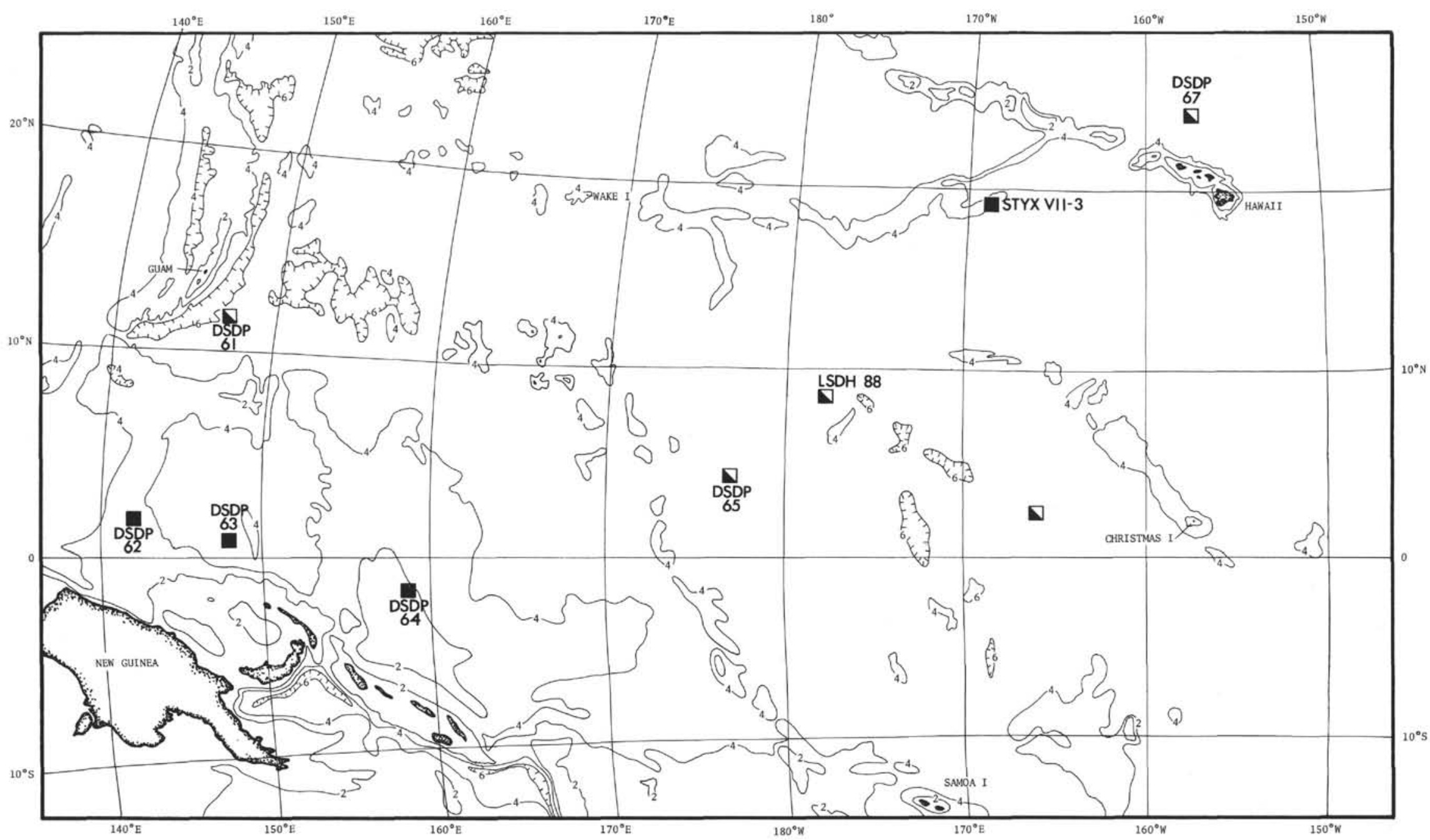

Figure 1. Location of deep-sea chert samples from the central and western equatorial Pacific. Associated with carbonate sediments,

Associated with siliceous sediments.

DSDP samples collected during Leg 7, LSDH and STYX sample collected by Scripps Institution of Oceanography expeditions LUSIAD and STYX. Depth in kilometers, contour interval 2 kilometers (after Menard, 1964). 
required to produce much greater quantities of chert. Whether or not the ultimate product will be rhythmically bedded is still open to question. Hopefully, later legs of the Deep Sea Drilling Project will be able to penetrate thicker and older chert sequences, and thereby provide an answer to this question.

\section{AGE OF CHERTS}

One of the striking early discoveries of the Deep Sea Drilling Project was the Eocene, and more particularly middle Eocene, age of most Atlantic deep-sea cherts. Although the Leg 7 cherts range in age from late Cretaceous to late Oligocene (Table 1), most of the bedded occurrences are of Eocene age, particularly those in the Central Basin. The previously mentioned problem of coring interbedded ooze and chert makes accurate determinations of the age of chert beds very difficult. Probably the best date for the top of the opaque layer in the Central Basin comes from Scripps core LSDH $88 \mathrm{P}$. Here, slightly porcelaneous cristobalitic claystone is directly overlain by radiolarian ooze belonging to the upper part of the Podocyrtis mitra Zone, that is from the upper third of the middle Eocene (T. C. Moore, personal communication). The other deep-sea chert from the equatorial Pacific collected by Scripps Institution prior to the Deep Sea Drilling Project, the large nodule from STYX 7, Station 3, contains poorly preserved nannofossils of probably late Lutetian age, again late middle Eocene (T. C. Moore, personal communication).

The widespread occurrence of these Eocene cherts points to a catastrophic, or at least abrupt change in geologic or oceanographic conditions about 45 to 50 million years ago. There is little evidence or necessity for a marked change in the silica budget to supply the material for the cherts. A relatively minor shift in the locus of biogenous silica deposition from present high to lower latitudes would provide vastly more reactive amorphous silica than is found in the Eocene cherts. The problem is rather one of identifying factors which would result in mobilization and concentration of silica in beds of a characteristic age. The Central Basin porcelanites are silicified cristobalite-(tridymite)-montmorillonite-(clinoptilolite) claystones, rather than silicified siliceous oozes, which are abundant above, between and below the cherts. This suggests that some chemical peculiarity of altering volcanic debris may be responsible for the accumulation of chemical silica. Alternatively, the volcanic debris may be no more than a by-product of some event which also modified oceanographic conditions near the sea floor. Temporary stagnation of the bottom water, due either to tectonic "silling" of large areas of the Pacific and North Atlantic Oceans (connected during the early Tertiary) or influx of dense hypersaline water (as perhaps suggested by the unusual mineralogy at Site 12 in the eastern North Atlantic,
Peterson et al., 1970) could lead to changes in $p \mathrm{H}$ or dissolved silica of sufficient magnitude to produce silicification of surface sediments.

The evidence for such a dramatic oceanographic event in the middle Eocene is far from conclusive. In part, this reflects the minimal amount of geochemical work done on Deep Sea Drilling Project cores so far, and in part, a lack of basic knowledge of the oceanographic parameters responsible for many of the geochemical and mineralogical peculiarities observable in deep-sea sediments.

Perhaps the only valid conclusions at present are that cherts in thick carbonate sequences are not isochronous, although they do occur most abundantly in the lower Tertiary, whereas cherts in noncarbonate sequences are commonly but not invariably first encountered in middle Eocene deposits. The catastrophists may be considered in the ascendency, but the battle is not yet over!

\section{MINERALOGY}

All three common polymorphs of silica are represented in the Leg 7 cherts. Cristobalite and quartz $(\alpha-$ forms in both cases) are the dominant minerals. Each ranges in abundance from less than 1 per cent to almost 100 per cent of chert samples. Tridymite is present in many cristobalite-rich porcelanites, and in associated claystone (? altered volcanic debris).

The quartz is generally chalcedonic in thin section. It yields sharp X-ray diffraction patterns, indicating that crystallites are considerably coarser than $1000 \AA$. This high degree of crystallinity is found regardless of the abundance of the quartz or age of the sample.

The crystobalite, in contrast, is always poorly crystallized. The crystallite size normal to 101 , determined from the Scherrer equation (Klug and Alexander, 1954), ranges from about 50 to $130 \AA$. As is obvious from Figure 2, this crystallite size bears no simple relation to the age of sediments enclosing the chert. This does not prove, however, that the size is unrelated to the age of chertification. There simply is no means of estimating such an age. For comparison, the crystallite sizes of typical Quaternary, Lower Miocene and Upper Eocene radiolarian opals are also shown on Figure 2. It is clear that chert cristobalite, despite its poor crystallinity, consists of much more ordered silica than does opal. Conclusions based on the few data of Figure 2 should be viewed with some caution. Nevertheless, it appears that there is a clear gap separating the chert and opal data. This implies that chert does not arise by the crystallization of cristobalite on aging opal nuclei. 


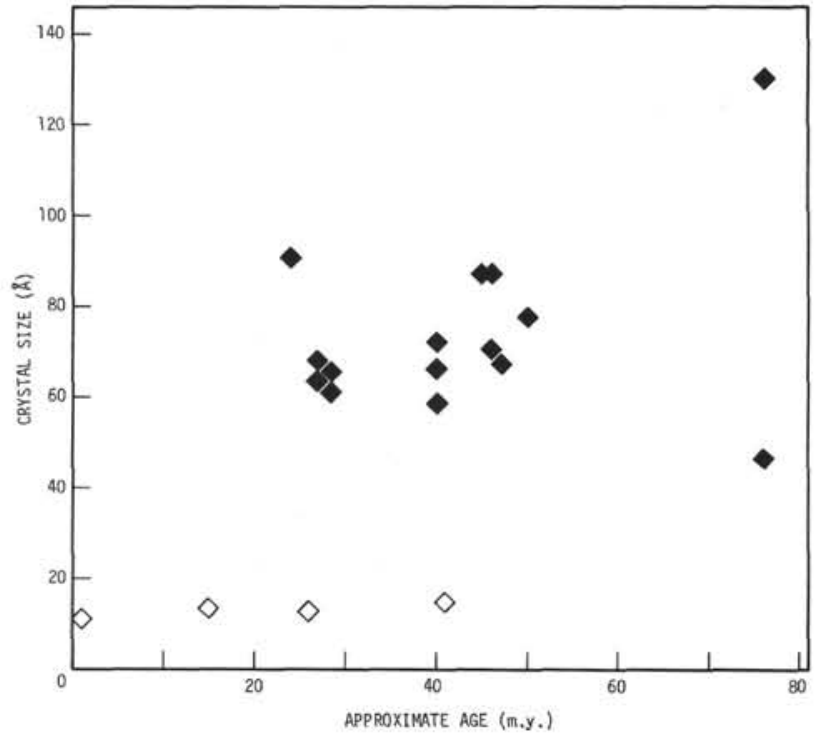

Figure 2. Size of cristobalite crystals normal to (101) as a function of geologic age. Deep-sea cherts-solid diamonds, radiolarian opal-open diamonds.

The ratio of cristobalite to quartz (based on the relative heights of their 101 reflections), like the crystal size, bears no simple relation to the age of enclosing sediment (Figure 3). Again, the age of nodule-formation is probably a more logical abscissa, but is indeterminate at present.

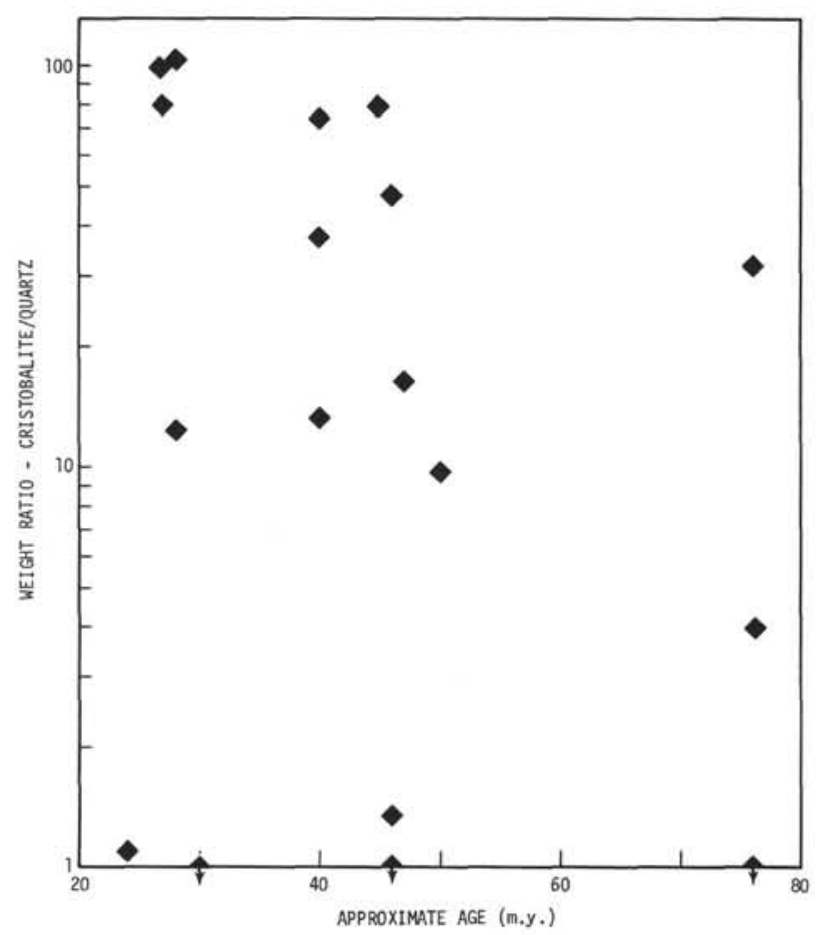

Figure 3. Cristobalite/quartz ratio in deep-sea cherts as a function of geologic age. Peak-height ratios converted to weight ratios using a factor of 9.5 (Rex, 1969).

Because cristobalite and tridymite are metastable under the conditions at which the nodules are found, it might be expected that they would be least abundant where the temperature is highest (providing it remains within the quartz stability field). This assumption is borne out by the mineralogy of silica adjacent to the intrusive basalt at Site 62. This silica is all quartz. Even 50 meters above the basalt, quartz is still abundant in chert nodules.

Unfortunately, in situ temperatures were not measured during the drilling of Leg 7 holes. However, the bulk density and water content of a sediment sample can be used to make a semi-quantitative estimate of its thermal conductivity (Langseth, 1965). Such values, together with the heat flow value and bottom water temperature at each site, plus the depth of the cherts below the sea floor, can be used to calculate crude in situ temperatures at the level of the cherts. The possible errors inherent in such a procedure are obvious, yet a plot of the relative abundances of cristobalite and quartz against such a temperature scale yields an intuitively reasonable pattern (Figure 4).

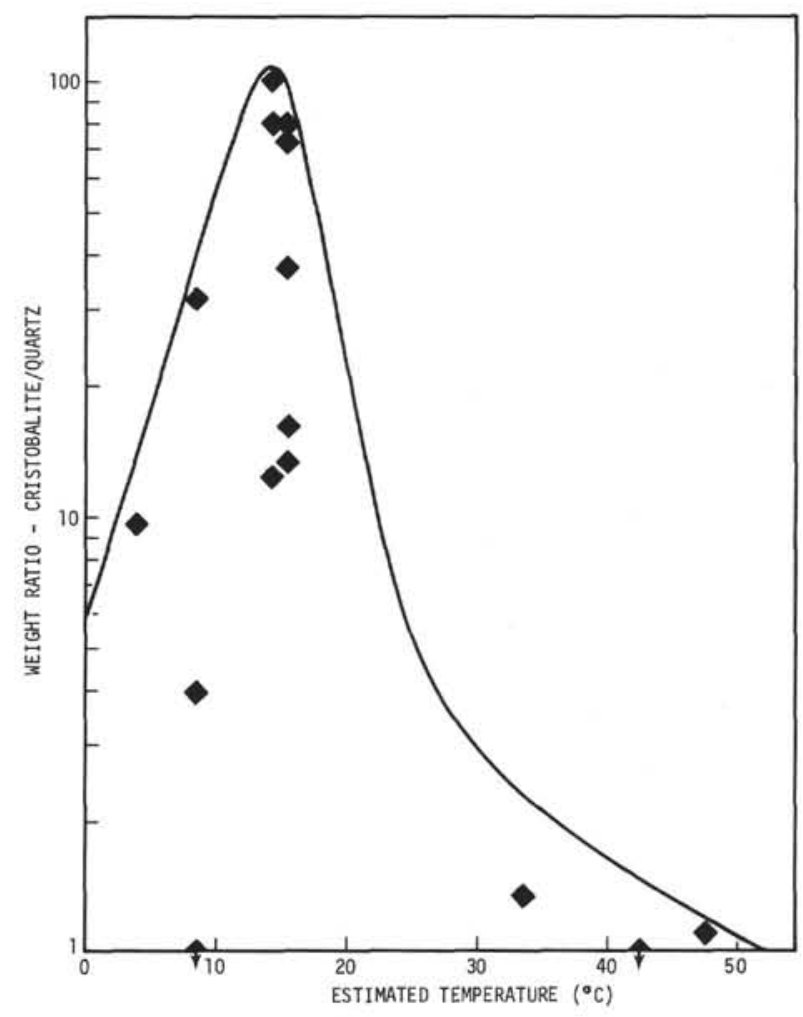

Figure 4. Variation of cristobalite to quartz ratio in Leg 7 cherts and porcelanites as a function of estimated in situ temperature. See text for method of deriving temperatures. Peak-height ratios converted to weight ratios using a factor of 9.5 (Rex, 1969).

At the lowest temperatures there are few cherts, and these tend to be fairly quartz-rich. Since these include the oldest (Cretaceous) samples, it is possible that, given enough time, quartz will form directly from 
dissolved silica. Alternatively, the chert may have formed at much higher temperatures than prevail at the site today. As will be discussed later, the age of thermal history of a sample almost certainly influence its mineralogy.

At temperatures in the vicinity of $15^{\circ} \mathrm{C}$, the ratio of cristobalite to quartz is at a maximum. This could mean that the conversion of opal to cristobalite is relatively rapid at this temperature, whereas the inversion of cristobalite to quartz is relatively slow. At higher temperatures, the second reaction is accelerated to the extent that quartz becomes the dominant or even the sole silica mineral (Figure 4), as is the case in samples close to intrusive basement.

Tridymite is present in many of the porcelanites from Sites 65 and 66 . Although its $4.30 \AA$ peak reflection is difficult to resolve from the $4.26 \AA$ (100) reflection of quartz, tridymite can be identified by comparing the composite $4.3 \AA$ peak with the $3.343 \AA$ (101) reflection of quartz. When tridymite is present, the spacing of the peaks exceeds the quartz value of $0.91 \AA$, and their intensity-ratio exceeds the normal range of 0.2 to 0.3 . In some of the Site 65 porcelanites, the $4.3 \AA$ reflection is twice as intense as the $3.34 \AA$ peak. Tridymite is most abundant in slightly indurated claystone from the core catcher of Core 17, Hole 65.0, and from the core catcher of Scripps piston core LSDH 88P. In both cases, the clay is rich in cristobalite, clinoptilolite and montmorillonite, and is probably altered volcanic debris. The presence of aluminum and other metal cation impurities appears to stabilize the tridymite structure (Buerger, 1954), but the parameters controlling its formation are not known. However, the unusually high concentrations of nonsilica minerals in the tridymite-bearing porcelanites points to the influence of readily available metal cations which may be necessary to initiate the formation of this mineral (Frondel, 1962).

\section{TEXTURE}

The nodular and bedded cherts show rather different textural characteristics. The nodules from carbonate sections will be considered first, since their textural features are most readily interpreted.

As mentioned in the chapter on "Siliceous Sediments", the first sign of silica cementation is the tangential "welding" of radiolarian tests. In extreme cases (such as, the chalk at the top of Core 8, Hole 64.0), this "welding" creates a spongy network of silica which can be freed by treatment of the rock with dilute acid, and then handled without destroying the original form of the rock fragments.
Such material, however, does not appear to be a precursor of nodular chert. In all the calcareous sequences sampled on Leg 7, the chert nodules are surrounded by a region containing severely corroded opaline skeletons or none at all. To the extent that this phenomenon negates the requirement for an exotic source of silica, it simplifies the interpretation of the chert occurences. However, it also eliminates the most promising source of evidence as to the factors controlling the locations at which nodules accrete. The same problem remains unsolved for nodular cherts in carbonate sequences on land. It is easy to present plausible arguments for subtle variations in $p \mathrm{H}$ or increased permeability at nodule locations, but in reality, it is still not known why nodules and networks of accreted silica favor certain stratigraphic levels. In any case, it appears the nodules in both shallow and deep-water carbonates derive their silica from opaline skeletal material deposited with the carbonate, rather than from external sources like volcanic exhalations.

The first stage in the formation of a nodule is the filling of empty foraminiferal chambers with silica (Figures 5 and 6). This silica is usually chalcedonic quartz, often as one or two generations of radiating bladed crystals. Cristobalite is rare, but occasionally lines filled the chambers.

The second stage is the replacement of the micritic groundmass of the carbonate rock (mostly nannofossils) by extremely fine-crystalline cristobalite (Figures 7, 8 and 9). The transition zone from virtually pure calcite to virtually pure silica is usually quite narrow, rarely more than 1 millimeter and occasionally as little as 50 microns. The anastomosing network of silica which characterizes the more irregular nodules results from the preservation of "islands" of carbonate, rather than from abnormally diffuse zones of silicification.

The third stage in the formation of a nodule is the replacement of foraminiferal tests by silica. This replacement is apparently a slow process, which occurs through crystal by crystal replacement of the radiating calcite prisms of the test walls (Figures 10 and 11). The resulting silica is in the form of radiating blades of chalcedonic quartz, which preserve both the shape and crystallographic orientation of the antecedent calcite.

The final infilling of pore spaces, which converts the somewhat porcelaneous replaced-chalk to "classic" chert apparently occurs later, and perhaps much later in the history of the rock. The textural evidence allows the silicification stages to be ordered in time, but cannot reveal the actual times involved. The rarity of dense vitreous cherts and the inverse relation of quartz content to porosity suggest that the final stage of silicification does not occur until the matrix cristobalite begins to invert to quartz. 


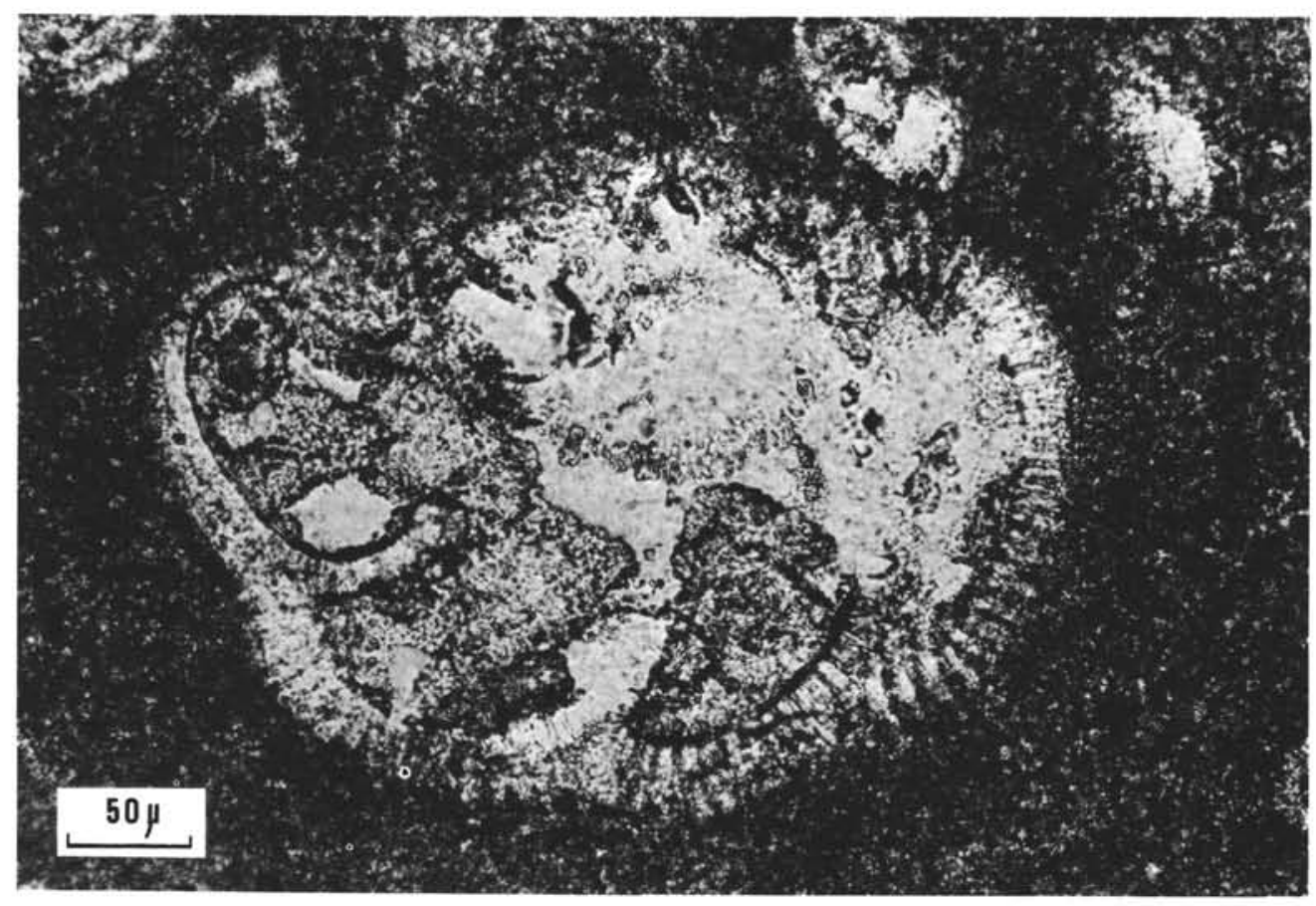

Figure 5. Foraminiferal test in nannofossil chalk filled with secondary chalcedony (clear). Bar is 50 microns long. Plane polarized light. 7-64-1-11-CC.

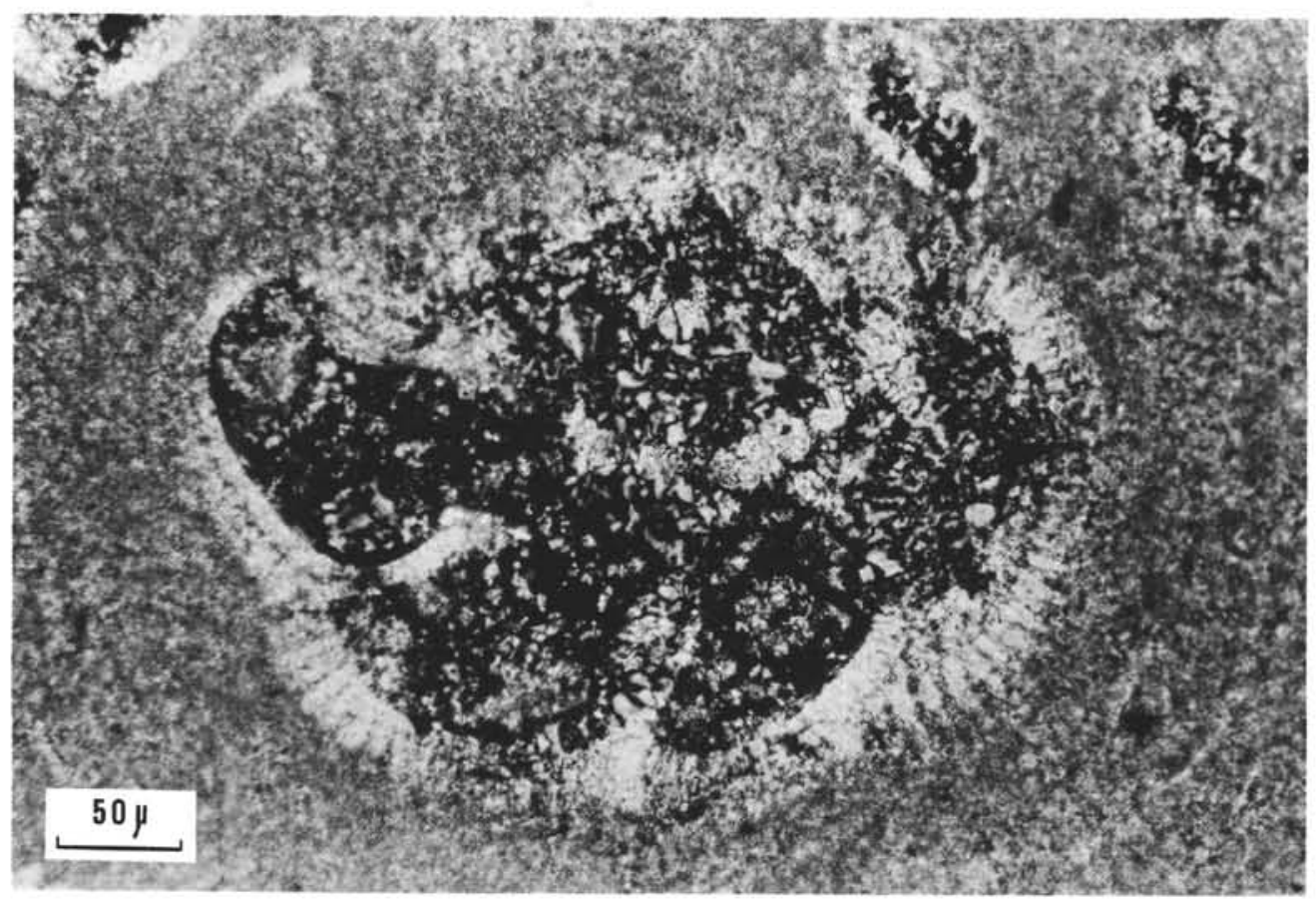

Figure 6. As Figure 5, but under crossed nicols. 


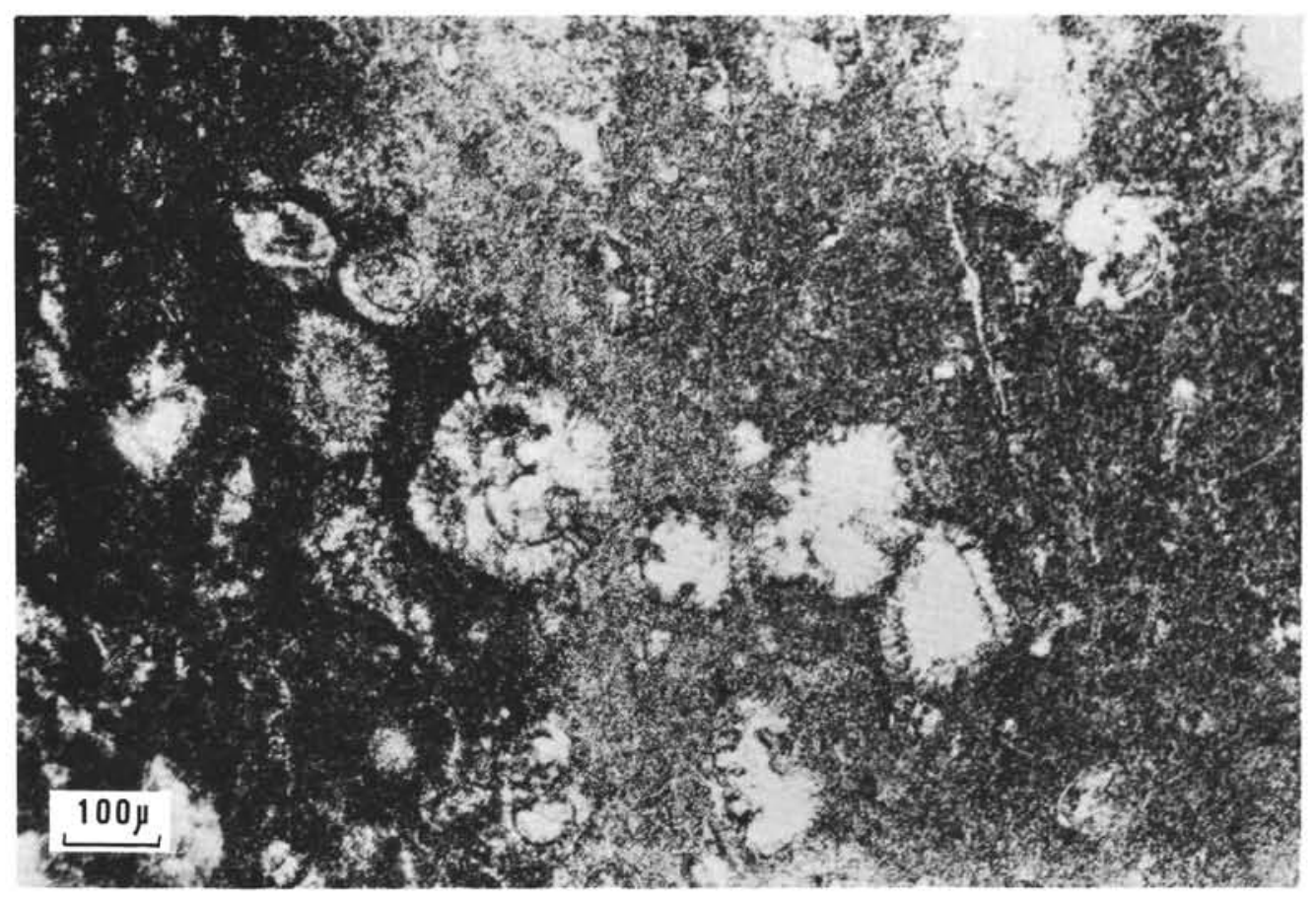

Figure 7. Contact between calcite (dark-nannofossils and foraminifera) and silica (cristobalite and lesser chalcedony) at the edge of a chert nodule in chalk. Bar is 100 microns long. Plane polarized light. 7-64-1-11-CC.

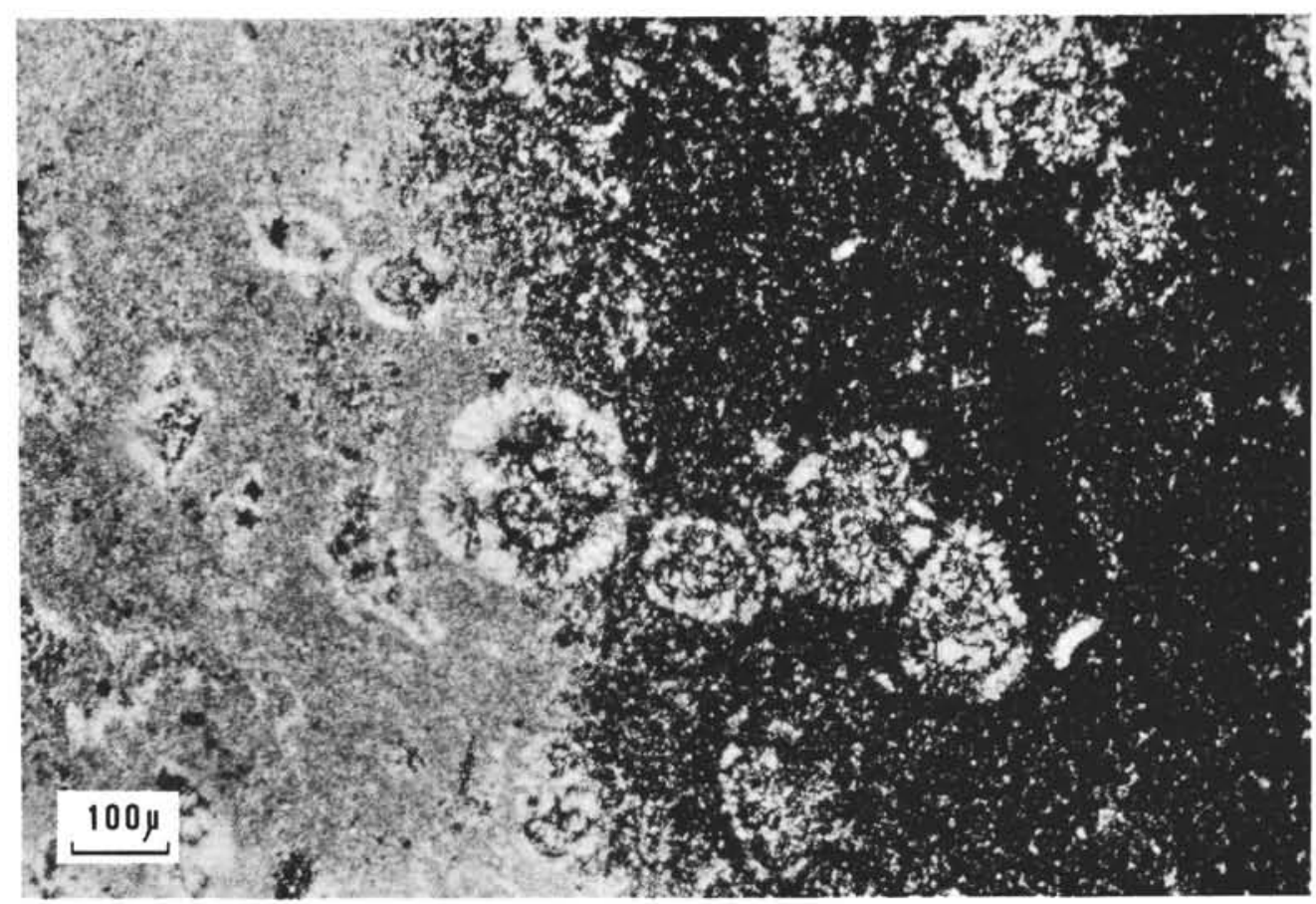

Figure 8. As Figure 7, but under crossed nicols. 


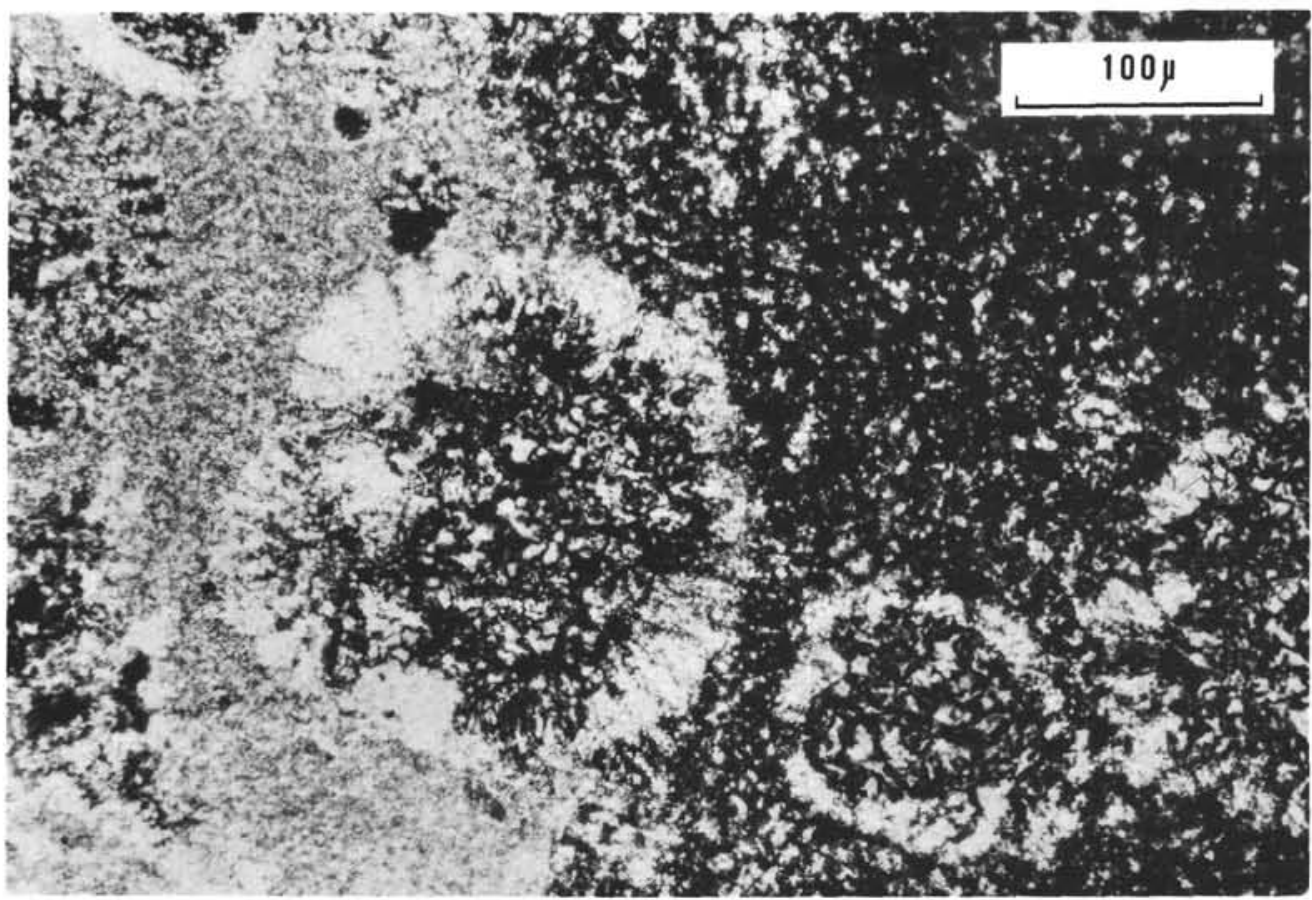

Figure 9. Enlargement of portion of Figure 8, showing sharp calcite-silica boundary. Bar is 100 microns long. Crossed nicols. 7-64-1-11-CC.

The bedded cherts are much more difficult to interpret because of their fine grain size.

The first stage in the formation of many of these cherts is the development of a cristobalitic and often tridymitic claystone, apparently by alteration of montmorillonite and perhaps amorphous volcanic debris. None of the claystones examined in thin section contains recognizable biogenous remains, so it is not clear whether the silica for the cristobalite is derived from opaline debris within the rock, from alteration of montmorillonite (or associated volcanic material), or from nearby opal-bearing beds.

The cristobalite-montmorillonite claystones (often containing clinoptilolite) are more indurated than associated pelagic clays, but are still quite friable, and often shrink markedly or disintegrate on drying.

The second stage of chert formation involves the crystallization of sufficient additional cristobalite to create a well-indurated porcelanite (Figure 12). The porosity and permeability of such a porcelanite is much less than the associated mudstone, but the two rock types are virtually indistinguishable in thin sections. Porcelanites of this type contain up to 100 times as much cristobalite as quartz - the highest proportion of cristobalite of any of the siliceous rocks sampled on Leg 7.
The radiolarian-bearing cherts (for example, at Site $61)$ are the most difficult to interpret. The preservation of siliceous tests is often excellent (Figures 13 and 14), and the tests are close packed, indicating that secondary silica was not derived from the solution of skeletons within the silicified bed. However, no examples of partly silicified ooze were sampled on $\operatorname{Leg} 7$, so the circumstances surrounding this type of silicification cannot be evaluated in this report.

The final stage in the formation of bedded cherts, as of nodules, is the inversion of cristobalite to quartz and the loss of virtually all remaining porosity. The inversion appears to spread from centers throughout the rock (Figure 15), creating clear masses of chalcedonic (and sometimes unstrained) quartz in place of the fine cristobalite mosaic. Where present, the interiors of radiolarian tests and the tests themselves are usually the first portions of the rock to invert. The recrystallization obliterates virtually all the siliceous skeletons preserved in the cristobalitic porcelanites.

\section{DEVELOPMENT OF CHERT}

The evidence from thin section and X-ray diffraction studies of the deep-sea samples, in conjunction with field observations and experimental work on exposed siliceous sediments, allows scientists to deduce something of the geochemical life history of a marine chert. 


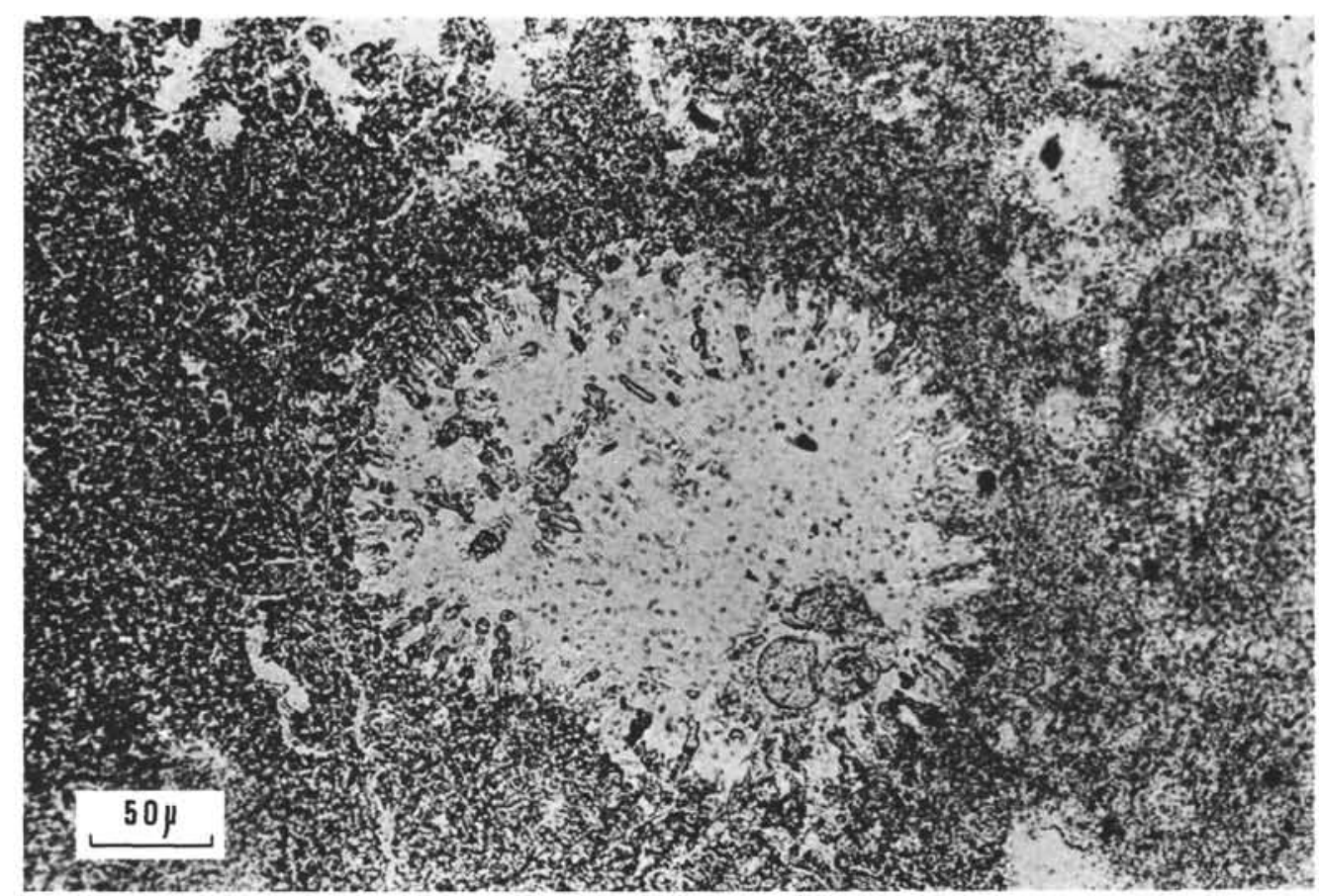

Figure 10. Foraminiferal test inside chert nodule filled and largely replaced by chalcedonic silica. A few calcite crystals remain. Bar is 50 microns long. Plane polarized light. 7-64-11CC.

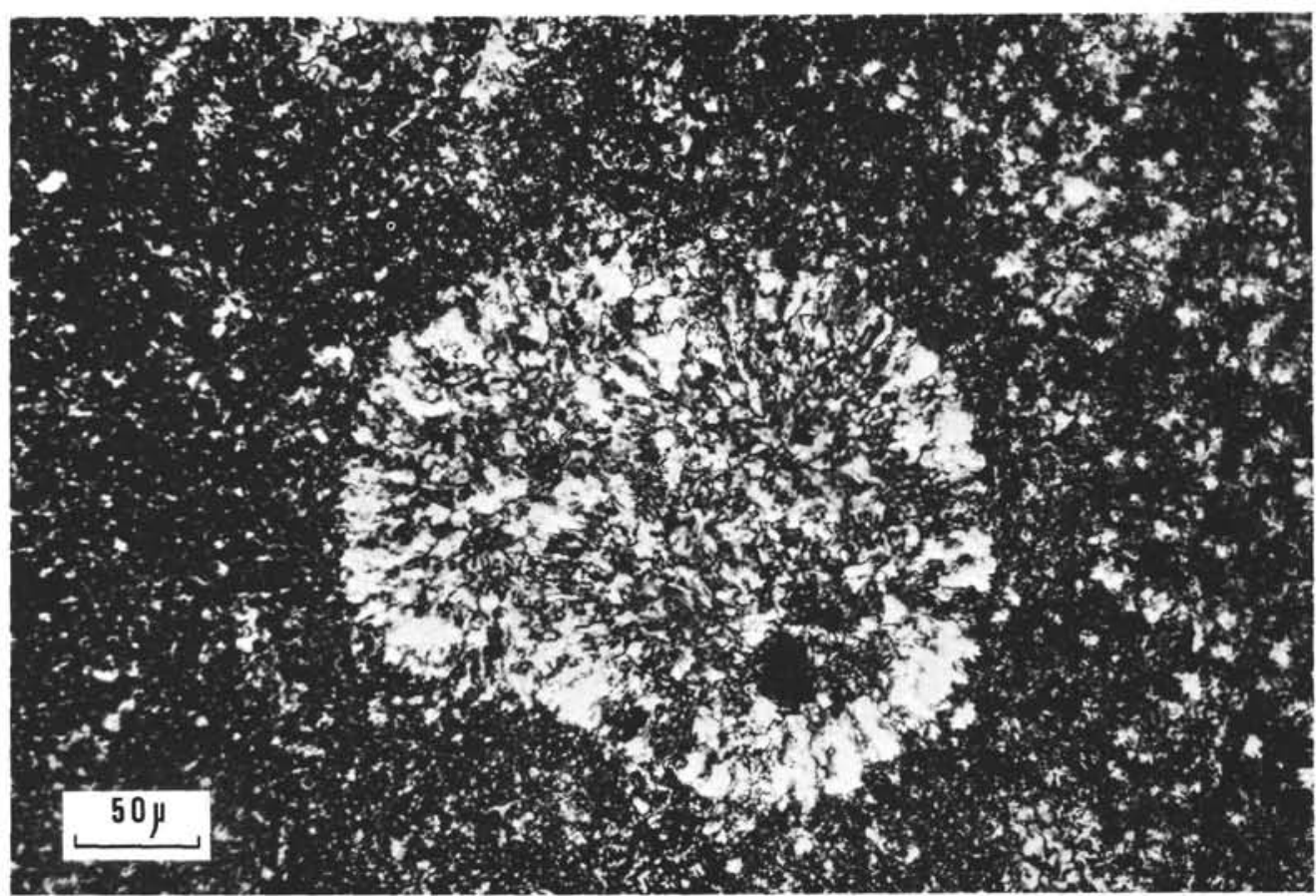

Figure 11. As Figure 10, but under crossed nicols. 


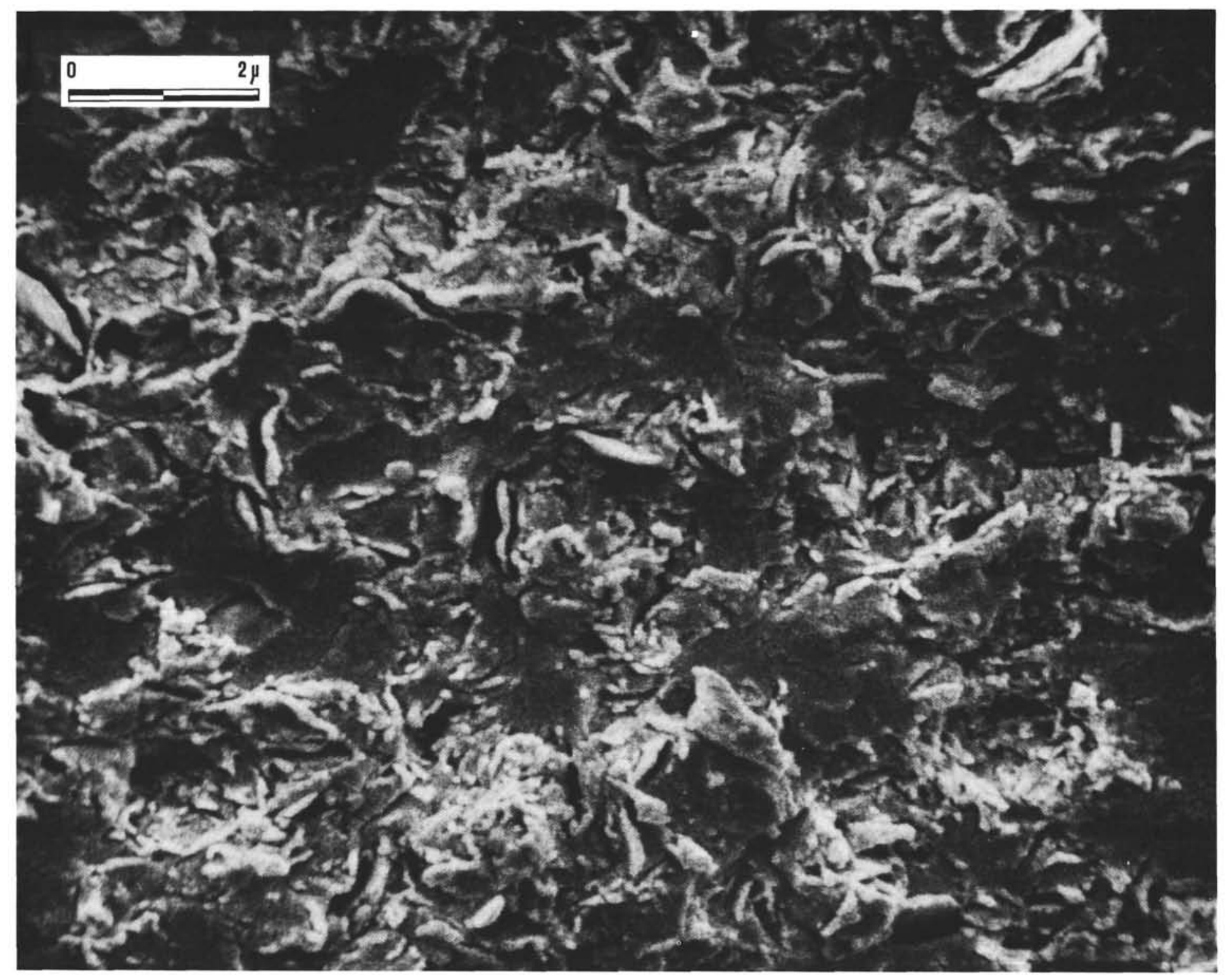

Figure 12. Electron micrograph of typical Central Basin porcelanite. Flakes are remnants of cristobalite-montmorillonite-clinoptilolite claystone which has been impregnated with cristobalite. Bar is 2 microns long. 7-66-0-4-CC. 


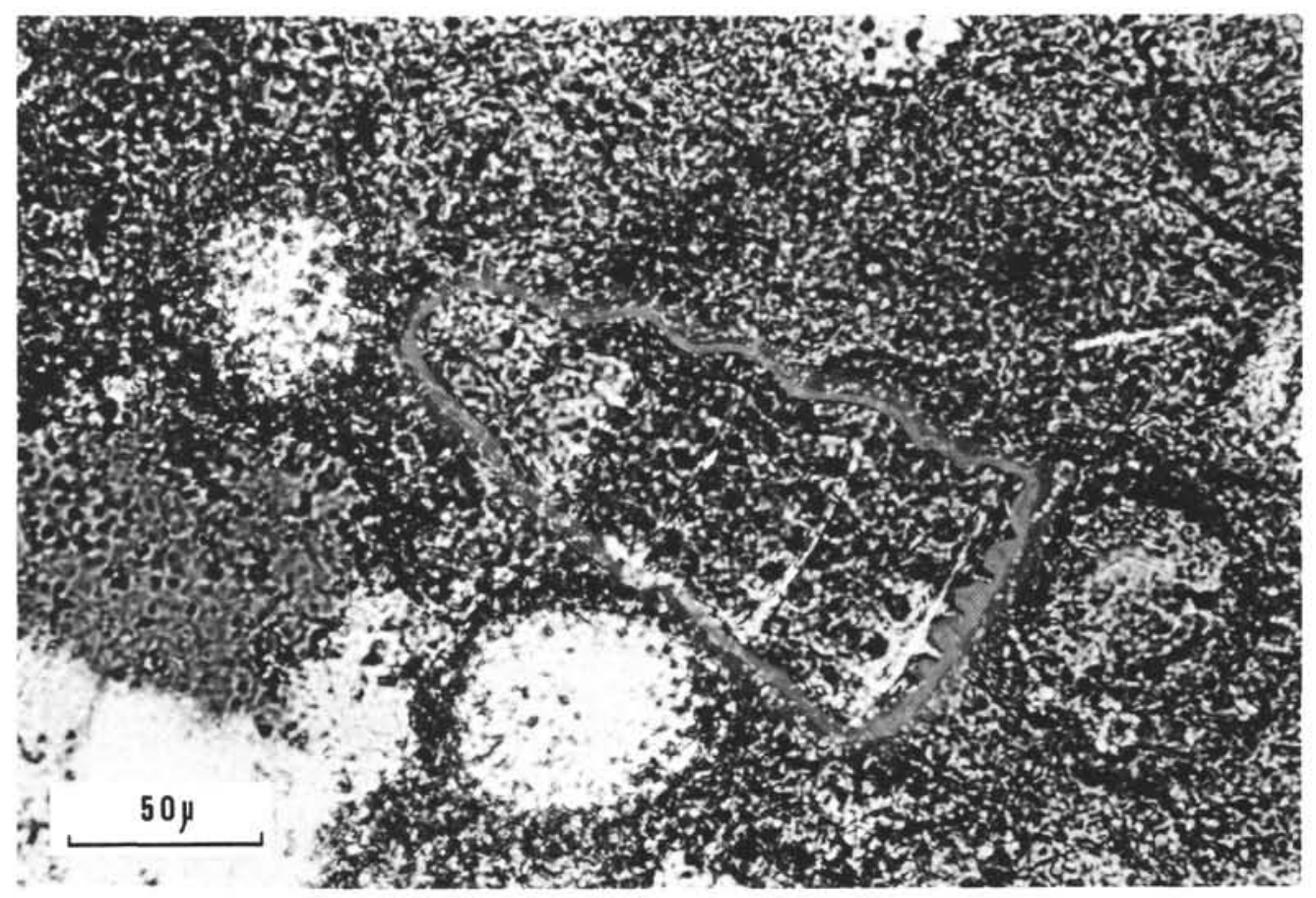

Figure 13. Costate dictyomitrid (radiolarian) in Cretaceous chert nodule, showing preservation of surface ornamentation (margin retouched). Bar is 50 microns long. Crossed nicols $25^{\circ}$ from extinction 7-61-1-1-CC.

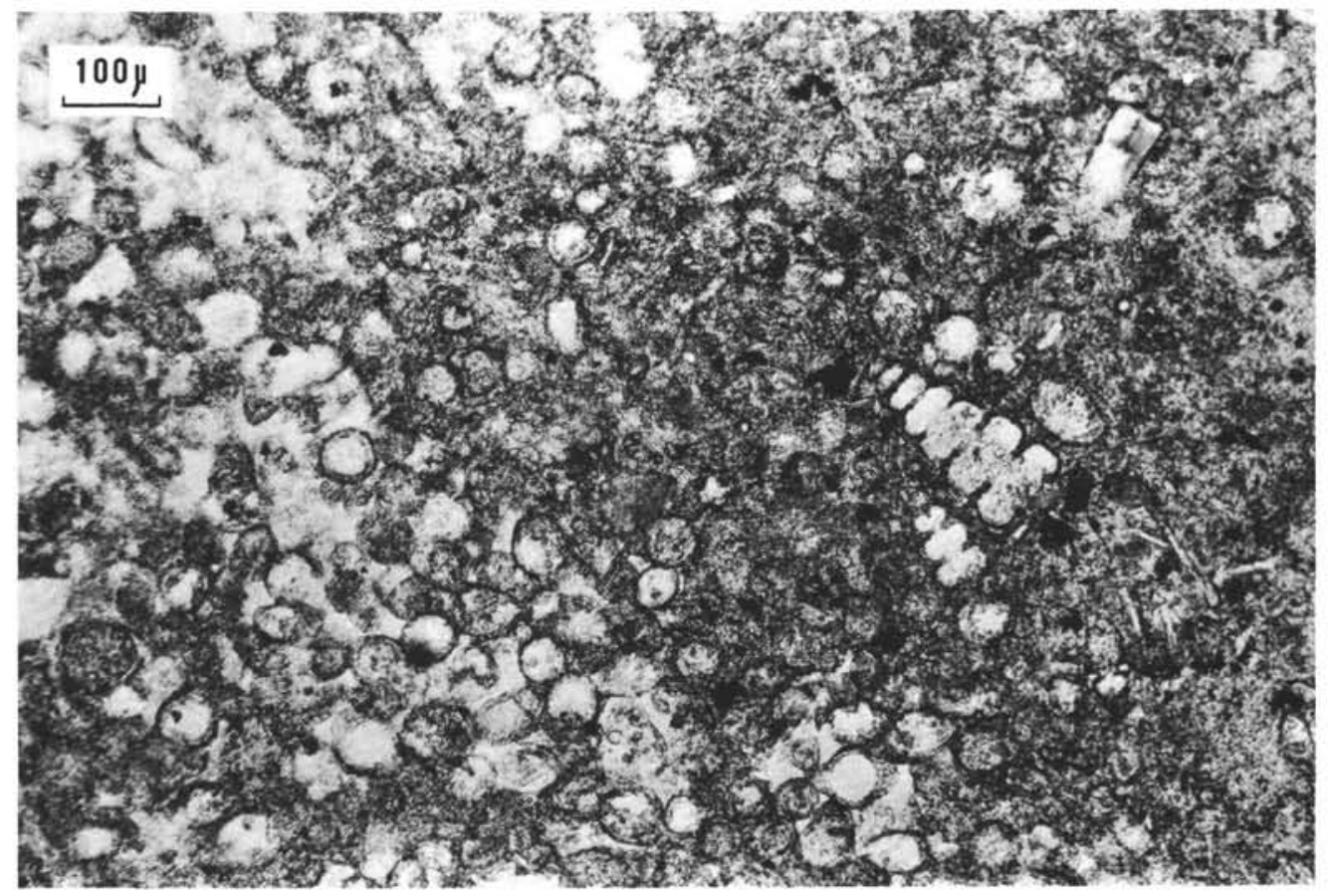

Figure 14. Cretaceous radiolarian chert, showing underformed closepacked siliceous tests in cristobalite (dark) and chalcedony (light) matrix. Bar is 100 microns long. Plane polarized light. 7-61-1-1-CC. 


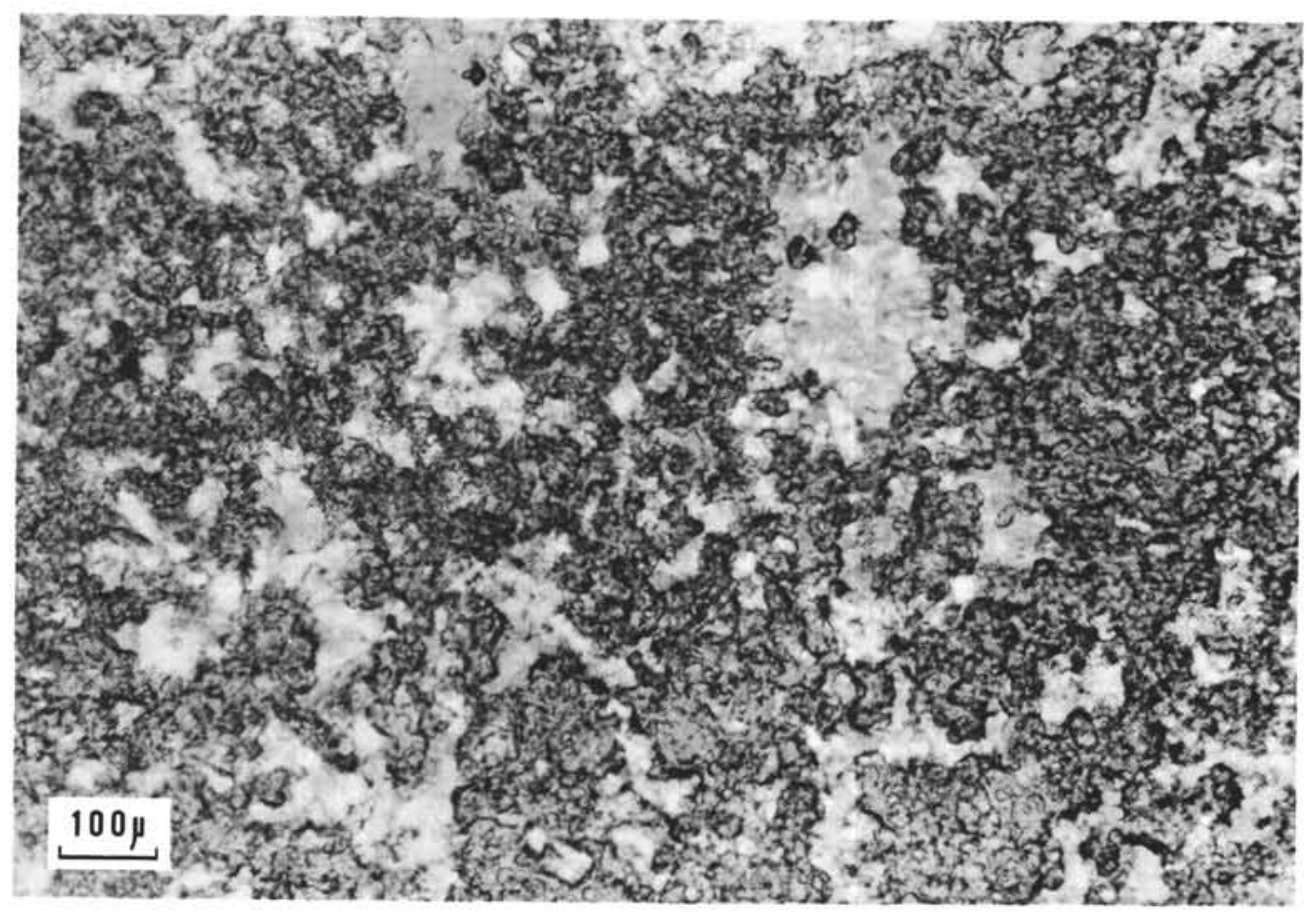

Figure 15. Cristobalite-quartz chert, showing irregular patches of chalcedonic quartz (light, low relief), developing by inversion of finely cristalline cristobalite. Bar is 100 microns long. Crossed nicols $15^{\circ}$ from extinction. 6-67-1-2-CC.

Both textural and mineralogical data indicate that the formation of chert is usually in a two stage process. Initially, the biogenous opal is converted to finely crystalline crystobalite, usually, but not always, in the form of porcelanite. Later, this cristobalite inverts to quartz, which is the characteristic constituent of all pre-Cenozoic cherts. What can be said about the chemical reactions involved in the two stages of this process?

The bulk of evidence from Leg 7 cherts indicates that the first stage involves dissolution of the silica. The absence of siliceous microfossils in most cherts, the presence of severely corroded siliceous skeletons or barren areas around cherts, and the volume of silica in the cherts indicate that the cristobalite silica must migrate distances of centimeters to meters from its point of origin to a growing chert mass.

The inferred solution step, while facilitating the migration of silica, complicates the interpretation of the mineralogy of the porcelanites. If the opal-porcelanite conversion involved a solid-solid transition, it would be easy to attribute the formation of cristobalite to the influence of "inherited" opal structure. However, since cristobalite is far from its stability field at sea-floor temperatures and pressures (Figure 16), its crystallization from solution is decidedly anomalous from a thermodynamic point of view. Two possible explanations could account for this anomaly. Firstly, by analogy with the carbonate system, it is possible that the direct precipitation of quartz, the thermodynamically stable form of silica, is inhibited by some other component of the system. Thus, magnesium ions in seawater inhibit the nucleation of calcite, the thermodynamically stable form of calcium carbonate under oceanic T.P conditions, and lead to the precipitation of an unstable form, aragonite. In the same way, cristobalite may be the only form of silica which can nucleate in interstitial solutions. The alternative explanation is that the dissolved opal consists of "domains" of sufficient size that they retain their original cristobalite structure. Such a hypothesis does not accord with existing knowledge of the state of dissolved amorphous silica, but cannot be dismissed until more is known of the chemical conditions prevailing in the sediment at sites of chert formation.

Experimental work on the alteration of opal to cristobalite is not particularly useful as a guide to reactions in deep-sea sediments. Mizutani (1966) states that the reaction is first-order with respect to silica, but his arguments include considerable circular reasoning, and his experimental conditions (particularly the use of $0.08 \mathrm{~N} \mathrm{KOH}$ as the interstitial medium) are so unlike those of the real world that little confidence can be placed in his results. Other investigations of the reaction are subject to similar criticism, and this problem appears unusually ripe for study at the present time. 


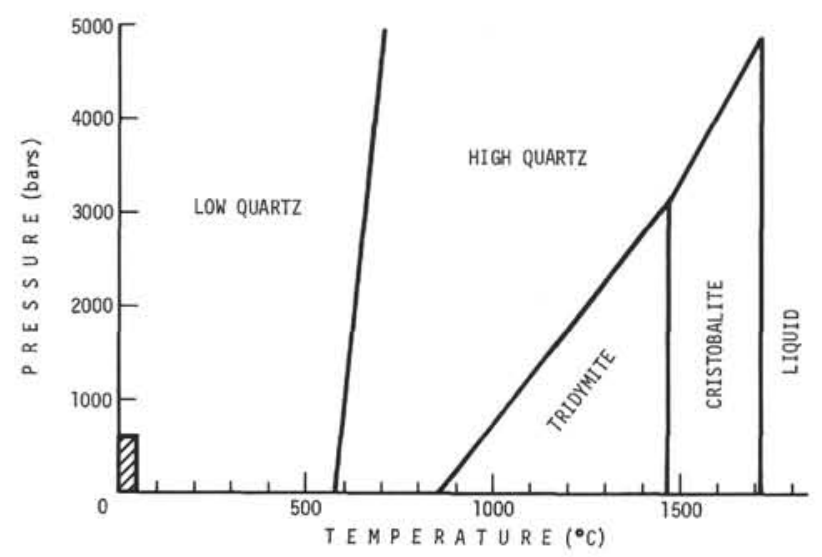

Figure 16. Pressure-temperature diagram for $\mathrm{SiO}_{2}$ (after Tuttle and Bowen, 1958). Shaded area is P-T field enclosing in situ conditions of Leg 7 cherts.

Field data for Cenozoic opal-porcelanite occurrences are open to the same range of interpretations as the deep-sea samples. Thus, the Monterey Formation includes porcelanite which contains fragmented diatom frustules in a fine-grained cristobalitic matrix (Bramlette, 1946; Ernst and Calvert, 1969). Lateral facies changes from diatomite to porcelanite are not accompanied by significant changes in the thickness of mapped beds, suggesting that the cristobalite has not developed by partial solution of opal within the beds. However, the field evidence is equivocal, and neither the precise source of the matrix silica nor the distance it has migrated have been satisfactorily established.

The second reaction, the inversion of cristobalite to quartz, is somewhat easier to interpret, both because of some unusually unequivocal textural evidence and because recent experimental work by Ernst and Calvert (1969) is directly applicable to deep-sea chert.

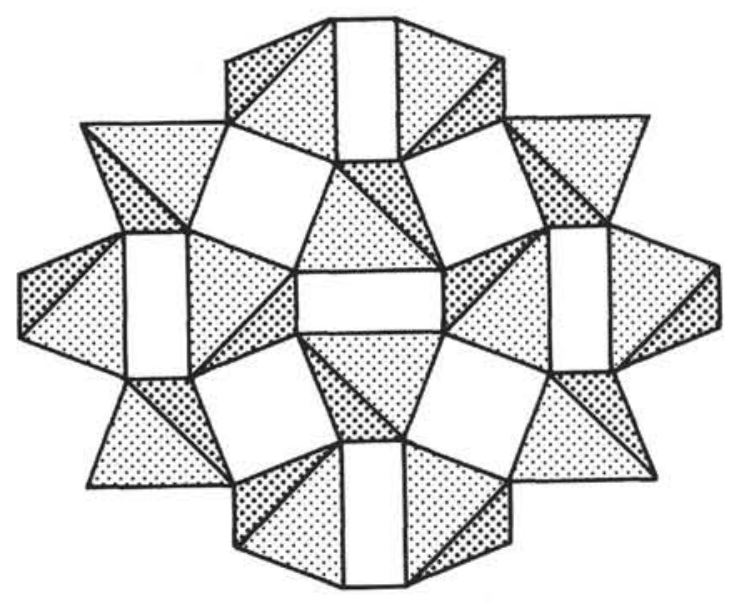

(a)
Quartz is thermodynamically stable in deep-sea sediments, whereas cristobalite is not. Therefore, the persistence of the latter mineral for tens of millions of years indicates that the activation energy for the inversion is large. In fact, Ernst and Calvert (1969) calculate a value of $23 \mathrm{kcal} / \mathrm{mole}$ for this reaction. Since the free energy of formation of both quartz and cristobalite is about $197 \mathrm{kcal} / \mathrm{mole}$ (Fournier and Rowe, 1962), the large activation energy indicates that the inversion requires a drastic reorganization of bonds within the crystal lattice. The necessity for such reorganization becomes apparent when one compares the structures of the two minerals (Figure 17). It is not surprising that cristobalite is quite stable at low temperatures, and requires either a great deal of time or a source of thermal energy to invert to quartz.

Ernst and Calvert (1969), on the basis of an extensive series of hydrothermal experiments on porcelanite from the Monterey Formation, conclude that the inversion is zero-order. They picture an inversion front migrating through each cristobalite particle at a velocity which depends only on the temperature. Such a concept is strikingly supported by textural relations in a cristobalite-quartz vein in a porcelanite from Hole 65.0 (Figures 18 and 19). The saw-tooth contacts between the high-relief cristobalite and low-relief chalcedonic quartz are classic solid-solid inversion fronts. The low porosity of the two mineral masses in this occurrence virtually excludes the possibility of a solution phase, except perhaps in a thin film at the inversion fronts. It also eliminates the requirement for additional silicification at this stage in the history of the rock.

Unfortunately, such clear-cut examples are very rare, and most quartz-bearing cherts show evidence of a more complex recrystallization history. In general, quartz appears to nucleate at many points in a given porcelanite, and increases in abundance by an increase in the

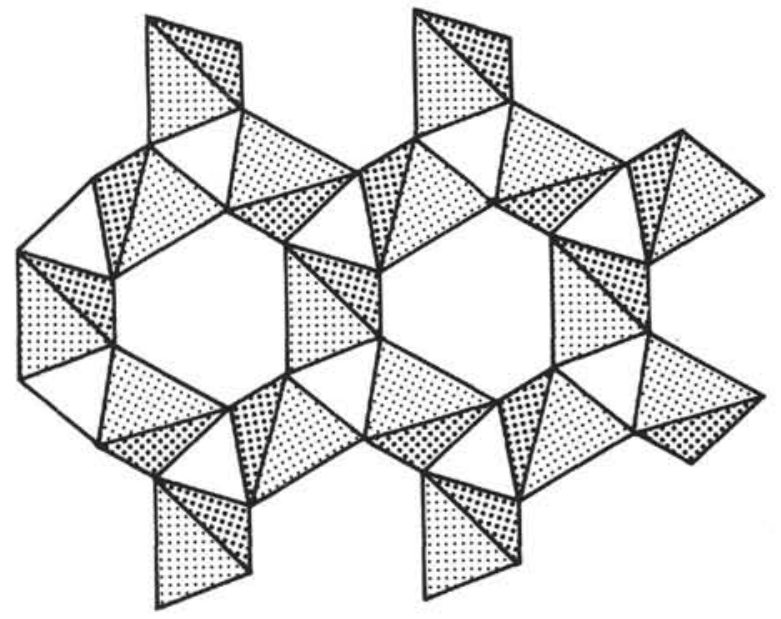

(b)

Figure 17. Crystal structure of (a) $\alpha$-cristobalite projected on (001) and (b) $\alpha$ - quartz projected on (001) to illustrate bond reorganization which must accompany inversion. $\mathrm{SiO}_{4}$ tetrahedra are shaded. Adapted from Deer et al. (1963). 


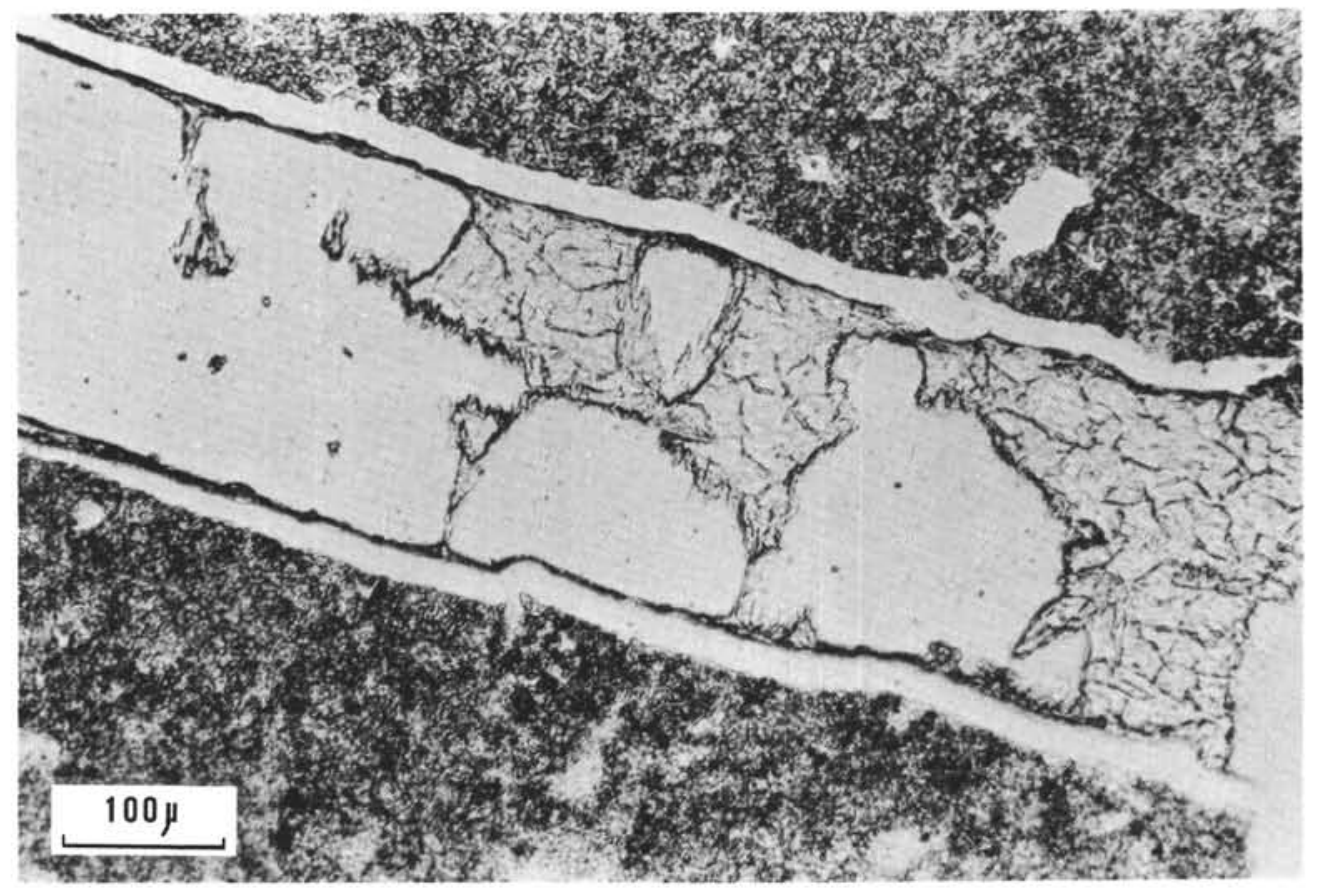

Figure 18. Vein of silica in cristobalitic porcelanite showing "frozen" cristobalite (highrelief) - quartz (low relief) inversion fronts. Bar is 100 microns long. Plane polarized light. 7-66-0-5-CC.

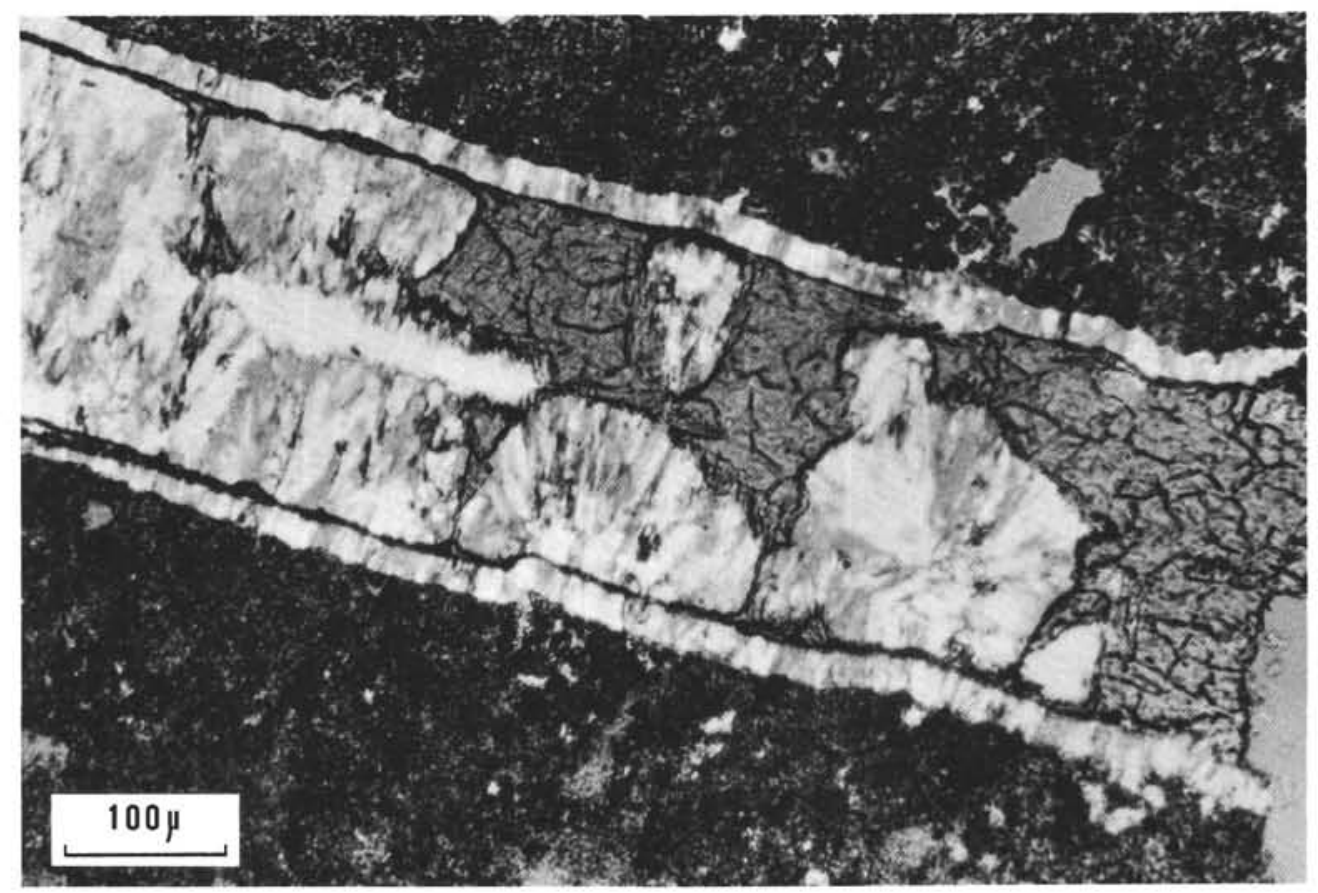

Figure 19. As Figure 18 , but crossed nicols $10^{\circ}$ from extinction, to show radiating sheaves of chalcedony. 


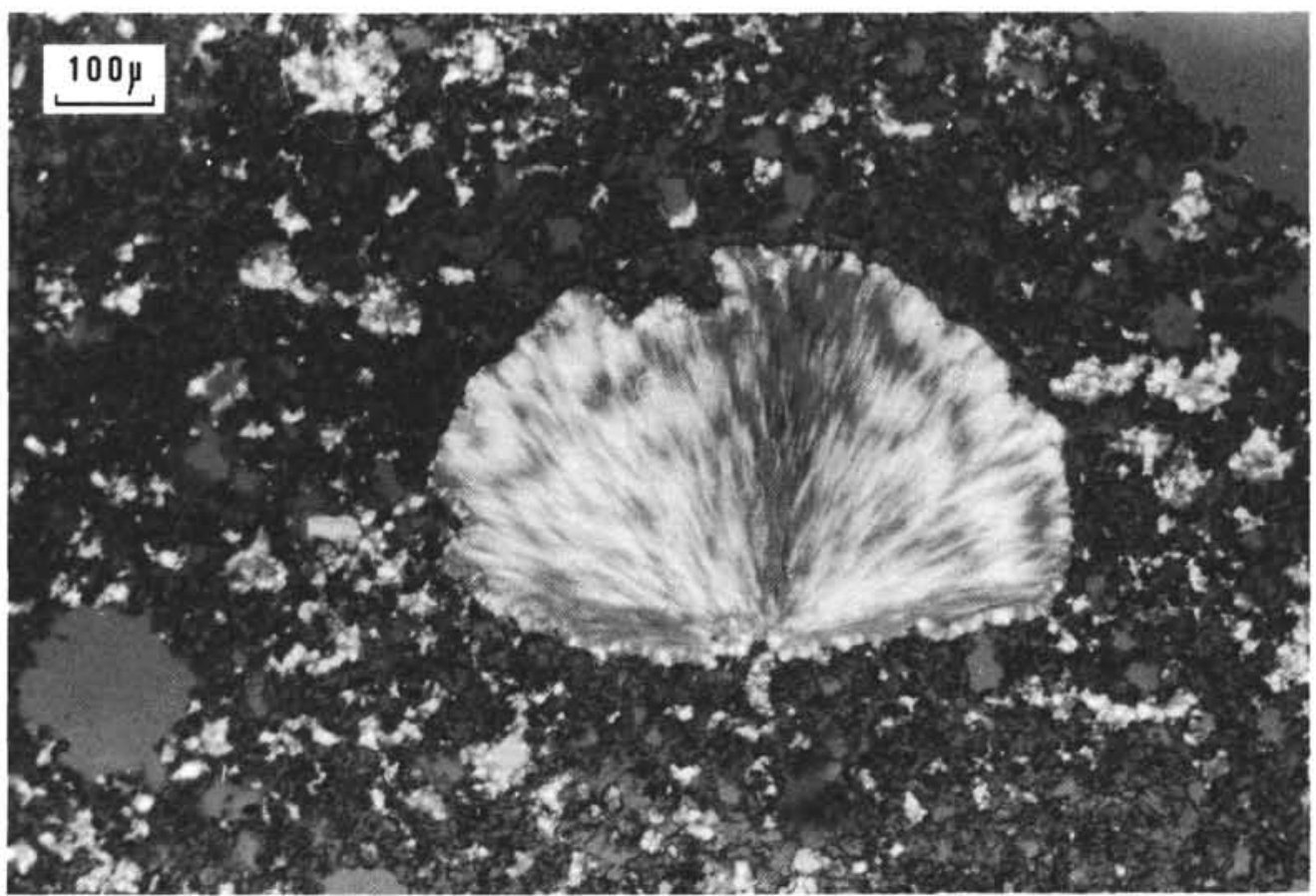

Figure 20. Masses of chalcedonic quartz growing by inversion of finely crystalline cristobalite. Bar is 100 microns long. Crossed nicols $10^{\circ}$ from extinction. 7-67-1-2-CC.

size of nuclei as well as the appearance of new nuclei (Figure 20). Because the quartz masses are considerably less porous than the original cristobalite, and because the growth of quartz masses is accompanied by severe degradation or destruction of textural features within the cristobalite (such as, molds and tests of siliceous organisms), at least partial solution of silica must accompany the inversion. To what extent this is an incidental phenomenon, rather than evidence for a distincly different mechanism from that proposed by Ernst and Calvert, remains to be established.

One of the most important reasons for understanding the chemistry of chert formation is related to its potential use as a paleotemperature indicator. Clearly, if the Ernst-Calvert model is correct, young cherts rich in quartz provide strong evidence of abnormally high temperatures within the enclosing sediments. Hopefully, further experimental work guided by observations of textural features and mineral associations within the deep-sea cherts will allow such evidence to be quantified.

\section{ACKNOWLEDGEMENTS}

Sincere thanks are due to T. C. Moore, Jr., W. R. Riedel and J. Lipps for stratigraphic advice and for the electron photomicrograph (Figure 12). Discussions with E. L. Winterer, R. W. Rex, T. C. Moore and J. I. Ewing have been most helpful.

\section{REFERENCES}

Bramlette, M. N., 1946. The Monterey Formation of California and the origin of its siliceous rocks. U.S. Geol. Survey Profess. Paper 212. 57 pp.

Buerger, M. J., 1954. The stuffed derivatives of the silica structures. Am. Mineralogist. 39, (7-8), 600.

Deer, W. A., Howie, R. A. and Zussman, J., 1963. Framework Silicates. Rock-Forming Minerals, Volume 4. London (Longmans), $435 \mathrm{pp}$.

Ernst, W. G. and Calvert, S. E., 1969. An experimental study of the recrystallization of porcelanite and its bearing on the origin of some bedded cherts. Am.J. Sci. 267-A, 114.

Frondel, C., 1962. Silica Minerals. The System of Mineralogy. 7th edition. 3, New York (John Wiley), $334 \mathrm{pp}$.

Klug, H. P. and Alexander, L. E., 1954. X-Ray Diffraction Procedures. New York (John Wiley), 716 pp.

Langseth, M. G., 1965. Techniques of measuring heat flow through the ocean floor. In Terrestrial heat flow. Lee, W. H. K., (Ed.), Am. Geophys. Union, Geophys. Monog. No. 8. 58-77.

Menard, H. W., 1964. Marine Geology of the Pacific. New York (McGraw-Hill), 271 pp.

Mizutani S., 1966. Transformation of silica under hydrothermal conditions. Nagoya Univ., J. Earth Sci., 14, 56 . 
Peterson, M. N. A., Edgar, N. T., von der Borch, C., Cita, M. B., Gartner, S., Goll, R. and Nigrini, C., 1970. Site 12. In Peterson, M. N. A. et al., 1970. Initial Reports of the Deep Sea Drilling Project, Volume 2. Washington (U. S. Government Printing Office), 249.

Rex, R. W., 1969. X-ray mineralogy studies - Leg 1. In Ewing, M. et al., 1969. Initial Reports of the
Deep Sea Drilling Project, Volume 1. Washington (U. S. Government Printing Office), 354.

Sujkowski, Z. L., 1958. Diagenesis. Bull. Am. Assoc. Petrol. Geologists. 42, (11), 2692.

Tuttle, O. F. and Bowen, N. L., 1958. Origin of granite in the light of experimental studies in the system $\mathrm{NaAlSi}_{3} \mathrm{O}_{8}-\mathrm{KA}_{1} \mathrm{Si}_{3} \mathrm{O}_{8}-\mathrm{SiO}_{2}-\mathrm{H}_{2} \mathrm{O}$. Geol. Soc. Am. Mem. 74. 